\title{
Implications of Perceived Benefits and Snags on Consumer Attitude towards Insurance Policies
}

\author{
Geetha R, Bindhu A R
}

\begin{abstract}
Insurance industry in India is relied upon to contribute US $\$ 280$ billion by 2020.This portends a significant leap for Insurance companies in India. The increased awareness, ever expanding distribution channels, improved service quality and innovative products are all contributing to the robustness of Insurance business in India. Besides these, insurance companies in India have an enormous potential that is under tapped. This is significantly evident in the existing penetration rate which is meagre $3.69 \%$. Insurance industry in India has witnessed tremendous changes in the past decade, attributed to the dynamic changes in micro and macro factors such as- booming competition, changing demographic profile of the customers, government regulations, product innovation and technology interface. In the ensuing study an effort is made to identify and discuss the factors fostering or encumbering consumers from purchasing policies of Insurance companies. By adopting a diagnostic research design and survey technique, data was collected from around 124 sample elements that were chosen randomly using probability sampling method. Among the ten perceived benefits, high rate of return, tax benefits and policy tenure were found to be the key determinants positively influencing the buying behaviour of consumers. Similarly cumbersome terms and conditions, lack of transparency and procedural delays were found to be the factors that impede purchase action of consumers.
\end{abstract}

Index Terms: Policy Purchase Behaviour, Perceived Benefits, Snags, Consumer Attitude

\section{INTRODUCTION}

Insurance is most sought after as tax-saving instrument $\mathrm{u} / \mathrm{s}$ $80 \mathrm{C}$ of the Income tax act for Indian investors. Life insurance is a complex and high involvement product. Life Insurance in India was nationalized In 1956 and was established to protect the interests of the stakeholders. In 2000, Life Insurance industry in India was opened to private players with intent of increasing the density and penetration of life insurance in India. Life insurance sector of India is the biggest in the world and as its 360 million policies are expected to grow at a compounded Annual Growth Rate of about12 to 15 percent over the next five years. By 2020, India's insurable population is anticipated to touch at least 750 million people, as the average life expectancy is nearing 74 years.

Revised Manuscript Received on July 5, 2019

Dr. Geetha, Professor \& HOD with the Department of MBA, DSATM,Opposite Art of Living International Center, Udayapurar Kanakapura Rd., Bangalore-560082 (e-mail: hodmba@dsatm.edu.in)

Bindhu A R, Student, DSATM, Opposite Art of Living International Center, Udayapura Kanakapura Rd., Bangalore- 560082 (e-mail: bindhuar.0101@gmail.com)

\section{LITERATURE REVIEW}

The articles were reviewed using scientific survey technique under which all the review articles were recorded on a template in a prescribed sequence and were later reported to identify the factors relevant to the current study. Search gap was identified after an extensive literature survey. The research premise, research title, objectives, hypotheses, dimensions, constructs and variables for current research were determined based on the literature survey.

The main objectives in the previous research papers were to develop and standardize a measure to evaluate investment patterns in insurance companies. Most of the studies were exploratory in nature and involved surveys. The major gap found was inadequacy of empirical literature pertaining to the service quality and benefits related to perceived benefits and snags expected to affect the purchase behavior of consumers

\section{STATEMENT OF THE PROBLEM}

Life insurance companies in India are expected to grow 12-15\% annually for the next 3-4 years (Source: IBEF report 2018). This indicates huge potential for insurance firms. They are developing strategic initiative to augment sales. In this context, there is a need to gauge market demand for their services for the policies. This work is an endeavor to inspect the connotation between the various elements inflicting, demand for insurance policies of select insurance companies. It aims at analyzing the factors favoring or hindering the consumer demand for insurance policies.

\section{SCOPE AND RATIONALE}

The area of the existing study is confined to 124 respondents, who are current or prospective insurance policy purchasers. The sample elements were randomly chosen from Bangalore, Hassan, Uttar Karnataka district from Karnataka state. The factors considered for the study include - (liquidity, company reputation, high return, low risk, tax benefit, information and advisory support) and commonly encountered problems.

Like; lack of awareness, reminder calls, tax deduction at source, lengthy and complex terms and conditions, financial burden, poor service quality, lack of transparency and delay in the procedures). 


\section{OBJECTIVES}

1. To recognize the elements that have significant impact on the demand for insurance policies

2. To analyze the factors favoring the purchase of insurance policy by consumers

3. To examine the problems associated with insurance policy purchase

4. To evaluate the implication of various determinants that influence purchase behavior either positively or negatively

5. To suggest suitable measure to improve sales of insurance companies based on the findings of the study

\section{RESEARCH PREMISE}

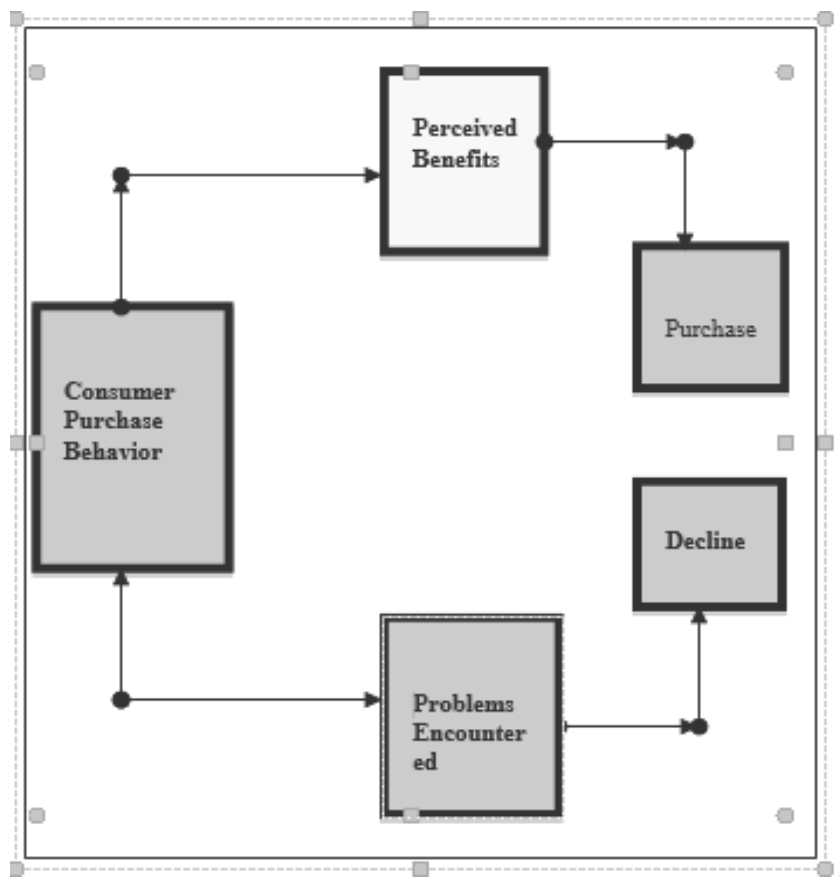

Fig-1: Source: Developed by authors

\section{RESEARCH METHODOLOGY}

Diagnostic research design was adopted to examine the influence of various perceived benefits and likely problems on insurance policy purchase behavior. Both Exploratory and Descriptive research designs were adopted for the current study. A structured questionnaire was used as a research instrument through which primary data was collected from 124 samples elements drawn from a population of insurance policy purchasers. Secondary data was collected from journals, references, internet search and other database repositories. The second section focused on obtaining the opinion of the respondents on stimulants and deterrents influencing their purchase behavior. Sample elements were chosen through simple random technique under probability method. Tools used for data analysis include percentage analysis, Cronbach alpha test, and Karl Pearson's correlation coefficient test.

\section{HYPOTHESES}

Hypothesis-1: Ho1: Cetirus Paribus, insurance policy and perceived benefits are not statistically correlated

Hypothesis-2: Ho2: Cetirus Paribus, There is no statically significance correlation between increased sales in insurance policy and the problem encountered by the consumers

IX. DATA ANALYSIS

Table 1: Demographic details of the respondents Demographic Details

\begin{tabular}{|c|c|c|c|}
\hline $\begin{array}{l}\text { Demographic } \\
\text { Characteristics }\end{array}$ & Categories & Frequency & Percent \\
\hline \multirow{3}{*}{$\begin{array}{l}\text { Gender Wise } \\
\text { Distribution }\end{array}$} & Female & 68 & 53.1 \\
\hline & Male & 56 & 46.9 \\
\hline & Total & 124 & 100.0 \\
\hline \multirow{6}{*}{$\begin{array}{l}\text { Classification } \\
\text { Based On Age }\end{array}$} & Less than 25 & 103 & 77.4 \\
\hline & $26-35$ & 16 & 12.0 \\
\hline & $36-45$ & 2 & 1.5 \\
\hline & $45-55$ & 2 & 1.1 \\
\hline & Above 55 & 1 & 8 \\
\hline & Total & 124 & 100.0 \\
\hline \multirow{6}{*}{$\begin{array}{l}\text { Classificatio } \\
\text { n based on } \\
\text { respondent's } \\
\text { income }\end{array}$} & $1-3$ & 48 & 38.1 \\
\hline & $4-6$ & 42 & 33.6 \\
\hline & $7-10$ & 14 & 12.5 \\
\hline & $11-15$ & 13 & 10.1 \\
\hline & $>15$ & 7 & 5.7 \\
\hline & Total & 124 & 100.0 \\
\hline \multirow{5}{*}{$\begin{array}{l}\text { Classificatio } \\
\text { n Based On } \\
\text { Qualification }\end{array}$} & $\begin{array}{l}\text { Below } \\
\text { Graduation }\end{array}$ & 17 & 13.8 \\
\hline & $\begin{array}{l}\text { Degree } \\
\text { Holder }\end{array}$ & 26 & 20.5 \\
\hline & $\begin{array}{l}\text { Post } \\
\text { Graduate }\end{array}$ & 38 & 31.4 \\
\hline & $\begin{array}{l}\text { Professional } \\
\text { Degree } \\
\text { Holder }\end{array}$ & 43 & 34.3 \\
\hline & Total & 124 & 100.0 \\
\hline
\end{tabular}

Table-1 is a snapshot of the demographic traits of the respondents surveyed. It may be observed that of the 124 respondents surveyed, $46.9 \%$ of them were male respondents and the remaining were female respondents. Nearly $77.4 \%$ of the respondents belong to an age cluster of fewer than 25 years and were typically from Hassan District. About $38.1 \%$ of the respondents fall in the income category of 1-3 lakh per annum. About $34.3 \%$ of the respondents were professional degree holders. Classification based on gender, age, income and qualification were considered to examine the differences in the opinion across categories of respondents defined by their demographic features.

Table 2: Consistency statistics of research elements 
Consistency Test

\section{Consistency Statistics}

Value of Cronbach's Alpha Number of Items

Table 2 The value of the Cronbach's alpha $(\alpha)$ for each of the perceived benefits and snags influencing the purchase decision of consumer indicates reliability and inter-item steadiness of the constructs considered in the research instrument which is used in measuring the concept of Consumer Purchase Behaviour (CPB)..

For the twenty eight causal factors considered to measure the research dimensions, the Cronbach's alpha value is 0 . 719 with alpha ' $\alpha$ ' scores positioned in a range of values between ( 0.710 to 0.720$)$, which demonstrates that the trials have acceptable inner reliability since they are above Nunnally's threshold limit of 0.70 . The results of the reliability test conducted helped in validating the questionnaire. They are shown in table 2. The ' $\alpha$ 'based on standardized items was ignored since all the variables used were statements with multi-point replies which typically included of the same answers on a five point rating scale with responses given in a descendent order with score between (Min value.-1 and Max value-. 5).

Karl Pearson Test

\begin{tabular}{|l|l|}
\hline $\begin{array}{l}\text { High Perceived Benefits Lead to } \\
\text { Increased Purchase of Insurance } \\
\text { Policies }\end{array}$ & Correlations \\
\hline Rate of Return & $0.222^{* *}$ \\
\hline Tax Benefit & $0.164^{*}$ \\
\hline & \\
\hline Policy Tenure & $0.164^{*}$ \\
\hline $\begin{array}{l}\text { Snags Deter Purchase of Insurance } \\
\text { Policies }\end{array}$ & Correlations \\
\hline Complexity of Terms and Conditions & $0.257^{* *}$ \\
\hline Lack of Procedural Transparency & $0.253^{* *}$ \\
\hline Delay in Renewal Notifications & $0.150^{*}$ \\
\hline
\end{tabular}

\section{MANAGERIAL IMPLiCATIONS AND LimitationS}

Managers of insurance companies may use research results to gain insights about the consumer attitude based on their preference for insurance policies. It facilitates them to understand the various factors boosting or encumbering the policy purchase behaviour of consumers. This in turn will help them in the formulation and implementation of appropriate strategies to influence the consumers to buy their policies based on the demand determinants identified through the study.

\section{FINDINGS}

1. High rate of return is observed to be most influential perceived benefit that determines the purchase behavior $(r=0.22)$ followed by tax benefit and policy tenure equally inflicting the policy purchase behavior $(r=0.164)$

2. The other factors like liquidity, company reputation, information and advisory support are paid less attention in deciding policy purchase

3. Lengthy and complex terms and condition is observed to be most likely problem which discourage the customers from buying insurance policy $(\mathrm{r}=0.257)$ followed by lack of transparency in procedures $(\mathrm{r}=0.253)$ and delay in renewal notice $(\mathrm{r}=0.150)$

4. The others factors like unknown reminder calls, tax deduction at source, payment delay to nominees are hitches faced by purchaser

$5.53 \%$ of the respondents were women and $47 \%$ of them were men of which $77 \%$ are below 25 years and belong to an income category earning between 1 to 3 Lakh. This implies that youngsters are brisk in purchasing protection policies

6. Majority of the respondents pay a premium between 1000-10000 INR per annum (Response rate-53\%)

\section{RECOMMENDATIONS}

1. Since the service related perceived benefits play a vital role in deciding purchase behavior of consumers insurance companies may pay greater attention to improve the service quality and other influential factors to boost their sales

2. The insurance companies may rethink an offering more benefits like high interest rates, bonus etc. as the results reveal that they have significant impact on purchase behavior of consumers

3. The promotional activities may be improved in order to reach out to as many consumers as possible since risk, poor service Quality, uncertain economic conditions, Unfavorable Government Regulations, Stringent and elusive terms and conditions discourage many consumers hence the Companies may train their personnel to provide counseling assistance to consumers.

\section{CONCLUSION}

Private life insurance organizations and LIC are making concerted efforts to improve penetration, and the real beneficiary is the customer. The marketers are also providing the newer customer engagement platforms and the internet technology providing ease of buying along with the information. Corporate image is determined by the experience of the customers and loyalty and repurchase are based on the post-sales services. Trust and transparency are the edifices on which Customer relationship is developed.

Determinants like Trained agents and ethics and motivation in selling are of

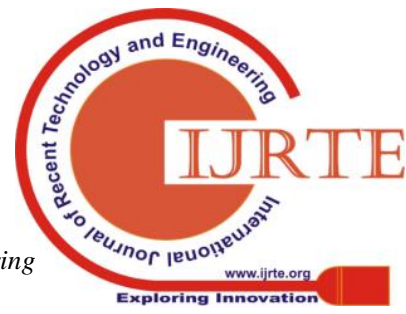


prominence in selling of insurance policies.

Tech savvy millennials prefer online buying of life insurance policies as it is convenient to them. To them online selling should be a safe and memorable experience.

Since financial services like life insurance are complex in nature, organizations need to manage the moments of truth and customer touch points carefully and provide satisfactory experience. Perceptual Mapping exposes the expected benefits and the encumbering factors affecting consumer attitude. Relevant Customer relationship management programmes have to be designed to foster positive customer experience so as to boost the sales of insurance companies. Future researchers may examine the types of policies most preferred by the consumers and they may also conduct research related to the demand estimation across income groups, gender categories and other demographic traits as that would pave for better analysis of consumer behaviour.

\section{REFERENCES}

1. Aaker, D. A., \& Shansby, J. G. (1982). Positioning your product. Business horizons, 25(3), 56-62.

2. Augustine, R., \& Chandrasekar, K. S. (2011). An empirical study on marketing orientation employed by life insurance companies in Kerala India. Journal of Marketing and Management, 2(2), 91- 102,104-107.

3. Ann E. Schlosser, Tiffany Barnett White, and Susan M. Lloyd (2006) Converting Web Site Visitors into Buyers: How Web Site Investment Increases Consumer Trusting Beliefs and Online Purchase Intentions.Journal of Marketing: April 2006, Vol. 70, No. 2, pp. 133-148.

4. Bellman, S., Lohse, G. L., \& Johnson, E. J. (1999). Predictors of online buying behavior. Communications of the ACM, 42(12), 32-38.

5. Bala, H. S. N. (2011). Customers' perception towards service quality of lifeInsurance Corporation of India: A Factor Analytic Approach International Journal of Business and Social Science, 2(18)

6. Brown, J. R., \& Goolsbee, A. (2002). Does the Internet make markets more competitive? Evidence from the life insurance industry. Journal of political economy, 110(3), 481-507.

7. Bridges, E., \& Florsheim, R. (2008). Hedonic and utilitarian shopping goals:The online experience. Journal of Business Research, 61(4), 309-314.

8. Berry, L. L., Wall, E. A., \& Carbone, L. P. (2006). Service clues and customer assessment of the service experience: Lessons from marketing. The Academy of Management Perspectives, 20(2), 43- 57.

9. Crosby, Lawrence. A., \& Stephens, N. (1987). Effects of relationship marketing on satisfaction, retention, and prices in the life insurance industry Journal of marketing research, 404-411

10.Choudhuri, P. S., \& Parida, B. B. (2014). Evaluation of Customers Expectation-Perception Score on Service Quality in Life Insurance Corporation of India. International Journal of Marketing \& Business Communication, 3(3)

11.Dutta, G., Basu, S., \& John, J. (2010). Development of utility function for life insurance buyers in the Indian market. Journal of the Operational Research Society, 61(4), 585-593

12.Devasenathipathi, T., Saleendran, P. T., \& Shanmugasundaram, A. (2007). A Study on Consumer Preference and Comparative Analysis of All Life Insurance Companies. Icfai Journal of Consumer Behavior, 2(4).

13.Durvasula, S., Lysonski, S., Mehta, S. C., \& Tang, B. P. (2004). Forging relationships with services: the antecedents that have an impact on behavioural outcomes in the life insurance industry. Journal of Financial Services Marketing, 8(4), 314-326.

14.Evans, F. B. (1963). Selling as a dyadic relationship-A new approach. The American Behavioral Scientist, 6(9), 76.

15.Gayathri, H., Vinaya, M. C., \& Lakshmisha, K. (2006). A pilot study on the service quality of insurance companies. Journal of Services Research, 5(2),123-138 conducted quantitative study the levels of the dimensions of service quality and its relation to the level of customer satisfaction in Mysore city

16.Ganguly, B., Dash, S. B., \& Cyr, D. (2009). Website characteristics, trust and purchase intention in online stores: an empirical study in the Indian context. Journal of Information Science and Technology, 6(2), 22-44.

17.Ghosh, A. (2013). Does life insurance activity promote economic development in India: an empirical analysis? Journal of Asia Business Studies, 7(1), 31-43.

\section{AUTHORS PROFILE}

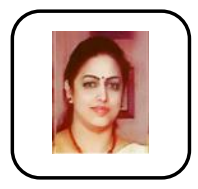

Dr Geetha has a career spanning 14 years as an academician and has had brief stints as an entrepreneur with Zee Network. She is specialized in Leadership Development, Strategic Talent Management, Knowledge Management, International Human Resource Management, OB, International Business, Managerial Economics and Macroeconomics. Her unique abilities and strengths as a professional are reflected by an exclusive professional experience in analytical skills, mentoring, lecturing, academic publishing, editing, research and content writing. She is a strong education professional with a $\mathrm{PhD}$ focused in Digital HRM from the University of Mysore. She has 26 research publications to her credit and is acknowledged among the top $10 \%$ of the authors on Social Science Research Network She has sequentially won 5 best paper awards in various international and national conferences hosted by reputed B-Schools. She has served as a track Chair and panelist at International Conferences held in various Institutions and is is also involved in other academic associations as a member of Board of Examination/Board of Studies and has delivered guest talks in reputed B-schools on Corporate Economics and Current trends in technology and Management.

She served as Managing Editor of TIJARCM, International Journal with ISSN and brought out 2 Volumes and 4 issues of the journal at RJSIMS. Besides, she is editorial member of Samyoga, International Journal of Management and ARSEAM,. She has organized and coordinated several FDPs, workshops, seminars, symposia and management fests at Institutions served.

Dr. Geetha served as a Peer reviewer for international journals - Canadian Journal of Management and Sustainability, ARSEAM and Chronicle. She is a recognized research supervisor of VTU and has guided $4 \mathrm{PhD}$ research scholars, During the span of her career as an academician she has guided close to 300 projects Management graduates of various Universities. Besides these, she is also a member of the professional associations and NGOs like NHRDN, SHRM, and SRCM and several others.

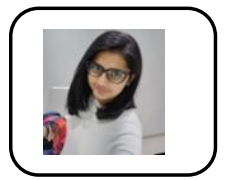

Ms. Bindhu A $\mathbf{R}$ graduated in Management from Dayananda Sagar Academy of Technology and Management which is affiliated to Visvesvaraya Technological University, Belagavi- Karnataka. She is currently employed as an Associate with FACE, a skill development company committed to create a world where every individual is able to realize his/her full potential and excel in their chosen careers'. Bindhu's areas of interest include- Market research, analytics and Human Resource Management, She is actively involved in research and publications. Recently she published a research paper in the proceedings of the National Conference- on Convergence of Science, Technology and Management-2019. y. She has a Bachelor's Degree in Engineering from the Visvesvaraya Technological University Belagavi.

During her tenure as a student at DSATM, she was actively involved in organizing and coordinating various HR-Club activities. Besides, she also has an aptitude for research and publication. Bindhu A R is self-motivated and independent. Apart from her MBA-curriculum bound courses, she has also completed several certified supplementary enrichment courses inDigital Marketing, Entrepreneurship Development, Professional Development, Advanced Excel, Aptitude Training, Innovation and Leadership Training and others. She was one of the Chief coordinators of HR -Event of Aavartan-18 and 19- Industry sponsored Management Fest hosted at DSATM. 